\title{
Epistemiese waardes in die rasionaliteitsmodel van Wentzel van Huyssteen
}

\author{
Jaco Kruger \\ Departement Filosofie \\ Potchefstroomse Universiteit vir $\mathrm{CHO}$ \\ POTCHEFSTROOM
}

\begin{abstract}
Epistemic values in Wentzel van Huyssteen's model of rationality

In his dialogue with the current state of the debate on philosophy of debate, Wentzel van Huyssteen develops what he calls a postfoundationalist model of rationality as opposed to the discredited foundationalist model and the, for him equally unacceptable, antifoundationalist model of rationality. In this article it is argued that the two basic epistemic values of Van Huyssteen's model, viz. the pursuit of intelligibility and the concept of critical realism, tie in with his opposition to foundationalism and antifoundationalism. He uses the concept of intelligibility to distance himself from a foundationalist approach, and then he utilizes the concept of critical realism to safeguard himself from antifoundationalism. The factor which ties these two values together is the notion of progress in science. In this article it is argued that Van Huyssteen's model does not really succeed in transcending the foundationalism-antıfoundationalism tension with a radically new alternative, the main reason for this being that a pragmatic idea of progress in science cannot succeed in integrally connecting the epistemic values of intelligibility and realism.
\end{abstract}

\section{Inleiding}

Die fokus van Wentzel van Huyssteen se werk is geleë in 'n dialoog met die hedendaagse probleembewussyn van ons kultuur. In die proses van verantwoording doen van sy geloof en van die geloofwaardigheid daarvan, moet die teoloog, volgens Van Huyssteen, die metateoretiese vraag na die aard en struktuur van sy eie denkmodel vra. Hierdie problematisering van die teologiese denkwyse is ' $n$ noodsaaklike voorwaarde vir ware kontekstualiteit in die teologie (Van Huyssteen, 1987:3). Die feit dat hier op metateoretiese vlak beweeg word (die teoloog besin oor sy eie denkprosesse) bring so 'n aanpak dadelik in verband met die wetenskapsfilosofie. Nog nader: omdat dit oor denkprosesse gaan, bring 
dit die teoloog (se besinning) in verband met die kenteoretiese vraag na die aard van rasionaliteit 1 .

In die huidige wetenskapsfilosofiese probleembewussyn is fondasionalisme as rasionaliteitsmodel ('n mens sou ook kon praat van metateorie) nie meer aanvaarbaar nie (vgl. Brown, 1988:78, 107, 132, 133; Wolterstorff, 1984:56, 57) 'n Fondasionalistiese benadering wil die sekerheid of betroubaarheid van 'n teorie bevestig deur dit op een of ander manier te verbind aan 'n "fondasie" van kwansuis ononderhandelbare sekerhede. Die ideaal het geblyk onbereikbaar te wees. A.an die ander kant bestaan daar vandag (volgens Van Huyssteen: in die postmodernistiese konteks) verskeie antifondasionalistiese benaderings tot wetenskapsbeoefening. In breë trekke kan gesê word dat dié benaderings wetenskap bloot op pragmatiese gronde wil bedryf (vgl. Rorty, 1989, vir 'n voorbeeld van so 'n standpunt; Brown, 1988:125-128 en Van Niekerk, 1992:hfst. 5 vir reaksie hierop.) So 'n aanpak is vir Van Huyssteen ook nie aanvaarbaar nie. Hy ontwikkel 'n sogenaamde postfondasionalistiese rasionaliteitsmodel vir die teologie waarin hy probeer om aan die probleme verbonde aan sowel fondasionalisme as antifondasionalisme te ontkom. Die volgende vrae ontstaan nou: hoe sien hierdie "postfondasionalistiese" model daar uit, en is dit werklik 'n post-fondasionalistiese model in die sin dat die spanning tussen fondasionalisme en antifondasionalisme oorstyg word?

In hierdie artikel word die twee kern epistemiese waardes waaromheen Van Huyssteen sy rasionaliteitsmodel bou, geïdentifiseer as (1) die nastreef van intelligibiliteit en (2) die idee van kritiese realisme. Daar word geargumenteer dat Van Huyssteen die nastreef van intelligibiliteit as epistemiese waarde gebruik om homself aan die een kant af te grens teenoor ' $n$ fondasionalistiese opvatting van rasionaliteit. Aan die ander kant lê hy weer sterk klem op kritiese realisme as 'n epistemiese waarde vir 'n postmoderne rasionaliteitsmodel om hom sodoende te stel teenoor die antifondasionalistiese (lees: relativistiese) uitlopers van die postmodernisme. Die instrument wat Van Huyssteen gebruik om hierdie twee waardes aan mekaar te bind, is die gedagte van vooruitgang in die wetenskap. Uiteindelik word tot die gevolgtrekking gekom dat Van Huyssteen nie werklik

I Rasionaliteit is een van daardic hoogs gelade begrippe ten opsigtc waarvan clke kecr opnuut weer uitgespel moet word wat daarmee bedoel word. Van der Merwe (1983:322) voer aan dat dic gesprek aangaande rasionaliteit grootliks wentel om twee puntc: (1) pogings om rasionaliteit gestand te doen teenoor irrasionalisme, en (2) analisc van dic aansprake van dic skeptisisme enersyds, en van 'n beroep op commitment andersyds Oprocpe klink vanuit verskeic corde op dat daar nuut gedink moct word oor dic begrip rasionalitett. Hart (1981:174) praat van dic huidige krisis in rasionaliteit; Brown (1988) handel oor dic probleme met dic "klassicke" opvatting van rasionalitcit en doen 'n alternaticf aan die hand: en Van Nickerk (1992:8-10) se sentrale hipotese is dat daar ' $n$ verruiming in die idee van rasionaliteit moct kom 
daarin geslaag het om die twee kante - intelligibiliteit en realisme - met mekaar te versoen nie, en dat die teenstelling tussen fondasionalisme en antifondasionalisme dus ook nie werklik getransendeer is in 'n postfondasionalistiese rasionaliteitsmodel nie ${ }^{2}$.

\section{Rasionaliteit as die nastreef van intelligibiliteit}

Van Huyssteen verbind die nastreef van intelligibiliteit aan iets wat eie is aan alle mense: die poging om die wêreld waarin ons leef, en wat in ons ervaring na ons toe kom, te verstaan. Die nastreef van intelligibiliteit is volgens hom altyd 'n reaksie op dit wat ons ervaar, dit is die strewe na die verstaan van die werklikheid op die diepste moontlike vlak. In die wetenskap neem die strewe na verstaan die vorm aan van 'n poging om op 'n ordelike en sistematiese manier verklarings van ons ervaring te gee. Die sluitstuk wat die begrippe "ervaar" en "verstaan" aanmekaar bind, is die opvatting van ervaringsmatige genoegsaamheid (experiential adequacy). Dié opvatting sê dat wetenskaplike denke altyd sal poog om op so 'n wyse 'n antwoord te gee op probleme wat uit ervaring ontstaan, dat dit 'n genoegsame verklaring sal wees vir dit wat ons ervaar (vgl. Van Huyssteen, 1993b:257). Hierdie is die vertrekpunt waarmee Van Huyssteen hom vereenselwig en waaruit die empiriese basis van sy rasionaliteitsmodel duidelik blyk. Nou kom 'n belangrike punt na vore: vir Van Huyssteen bestaan rasionaliteit in die wetenskap uit die aanvaarding van die beste moontlike verklarings (Van Huyssteen, 1993a:126). Dit gaan om die aanvaarding van die teoretiese modelle wat die mees effektiewe probleemoplossers is in terme van bepaalde kriteria. Van Huyssteen dui nie werklik aan of daar algemene kriteria is wat vir alle teoretiese uitsprake geld nie, behalwe om te sê dat kriteria vir effektiewe probleemoplossing gebonde sal wees aan die doel van die betrokke teoretisering (Van Huyssteen, 1988:82). Elders (Van Huyssteen, 1987:172) verskaf hy wel sy weergawe van die kriteria waaraan die rasionaliteit van spesifiek teologiese uitsprake getoets moet word

Dit blyk dus dat Van Huysteen baie vinnig en direk beweeg vanaf intelligibiliteit na die aanvaarding van teorieë wat probleme die effektiefste oplos. So 'n aanpak is dan volgens hom 'n kenmerkende karaktertrek van rasionaliteit. Dit wil vourkom asof hy, ten minste op die vlak van intelligibiliteit, wil wegstuur van kwessies oor die werklikheidsbetrokkenheid van teorieë, en eerder kies vir 'n breër, holistiese en meer pragmatiese benadering. Hy stel dit duidelik dat

2 Daar het al vanuit verske1e oorde reaksie gekom op Van Huysstecn se voorstelle. Smit (1988:91 e.v) lê veral klem op dic implikasies daarvan vir die tcologic. Krüger (1987:64-69) fokus op dic relevansic daarvan vir die verhouding tussen die Christelike teologie en ander religice Strauss (1991) se kritick op Van Huyssteen handel veral oor dic status van tcologie as 'n wetenskaplike dissipline, en oor die verhouding tussen taal en begripsvorming 
verklaring, sowel in die natuur- as die geesteswetenskappe, altyd ' $n$ vorm van rasionele rekonstruksie is. Rasionele denke is nooit suiwer objektief nie; die interpretatiewe teoretiseringsproses word tot 'n groot mate beïnvloed deur die konteks waarin dit plaasvind. Enige navorsingsprogram en die verklarings wat dit gee, is dus slegs voorlopig en kan slegs gedeeltelik op 'n spesifieke tydstip geëvalueer word (Van Huyssteen, 1993a:129); daarom dat rasionaliteit gekenmerk word deur die keuse vir die beste moontlike verklaring op 'n spesifieke tyd. So 'n opvatting van rasionaliteit probeer wegkom van die eng en rasionalistiese opvatting wat volgens Van Ifuyssteen dikwels in die verlede gehuldig is, en probeer reg laat geskied aan die feit dat rasionaliteit ' $n$ komplekse en veelkantige verskynsel is (Van Huyssteen, 1993a:126).

Uit die voorafgaande uiteensetting word dit duidelik dat Van Huyssteen die kognitiewe aspek van rasionaliteit, in elk geval in hierdie deel van sy argument, ietwat relativeer. Volgens hom kan daar in 'n breër en ryker opvatting van rasionaliteit ten minste drie bronne van rasionaliteit geidentifiseer word, waarvan die kognitiewe konteks slegs een is, en op gelyke vlak met die ander twee kontekste staan. Die drie bronne van rasionaliteit is die kognitiewe konteks, die evaluatiewe (morele) konteks en die pragmatiese konteks (Van Huyssteen, 1995:17). Die implikasie van hierdie drie bronne is dat rasionaliteit bestaan in die verskaffing van goeie redes waarom sekere oortuigings gehandhaaf word (kognitief), die verskaffing van goeie redes waarom sekere morele keuses gemaak is (evaluatief), en die verskaffing van goeie redes waarom op 'n sekere manier opgetree word (pragmaties). Hierdie drie kontekste gaan dan saam as 'n "naatlose geheel". Daar sou dus gesê kan word dat 'n mens rasioneel optree in sake rakende oortuiging, aksie en evaluasie wanneer die redes vir die optrede oortuigend en samehangend is (Van Huyssteen, 1993a:127). Die aanvaarding van 'n teorie as die beste verklaring het dus 'n kognitiewe dimensie, maar die pragmatiese en evaluatiewe dimensies is net so belangrik. Die afleiding wat nou gemaak kan word, is dat Van Huyssteen hoop om die sterk teenstelling van of fondasionalisme of antifondasionalisme te transendeer deur te fokus op pragmatiese en evaluatiewe dimensies.

Veral ten opsigte van die evaluatiewe dimensie van rasionaliteit gee Van Huyssteen 'n uiteensetting van wat hy met 'n breër en ryker opvatting van rasionaliteit bedoel. Die evaluatiewe dimensie van rasionaliteit fokus op die rol van beoordeling in menslike kognisie. Oordeel is dan in epistemiese sin die vermoë om 'n situasie te evalueer, om getuienis op te weeg en om dan tot 'n redelike besluit te kom sonder dat voorafneergelegde reëls gevolg word (Van Huyssteen, 1995:17; vgl. Brown, 1988:138 e.v.). Oordele moet gevel word deur individue wat beskik oor genoegsame, relevante informasie ten opsigte van die tersaaklike situasie. Die klem val op die spesifieke en kontingente parameters van 'n situasie cerder as op algemene en noodwendige kemnis wat kwansuis deur 
'n sekere metode van 'n vaste basis van sekerhede afgelei sou kon word. So 'n opvatting van rasionaliteit verteenwoordig vir Van Huysteen 'n stap vooruit ten opsigte van die klassieke fondasionalistiese rasionaliteitsmodel. Volgens dié opvatting behoort dit ook glad nie so 'n groot gewetenswroeging af te gee wanneer dit duidelik word dat ' $n$ bepaalde opvatting ten gunste van 'n nuwe een laat vaar moet word, indien goeie redes vir die aanvaarding van die latere een bestaan nie (Van Huyssteen, 1995:18).

'n Volgende aspek van 'n evaluatiewe benadering tot rasionaliteit is, volgens Van Huyssteen, dat naas rasionele oortuigings (d.w.s. oortuigings waarvoor goeie redes bestaan) ook rasionele persone belangrik is (vgl. Brown, 1988:185) Rasionele persone is mense wat hulle gesonde verstand kan gebruik en wat 'n goeie oordeel te midde van moeilike en komplekse omstandighede kan vel (Van Huyssteen, 1995:19). Van Huyssteen gaan nou verder en onderskei drie kenmerke van rasionaliteit waar die rasionele persoon vooropstaan.

- Die eerste kenmerk is dat 'n rasionele oortuiging een is waartoe deur ' $n$ rasionele agent gekom is; dit gaan oor die wyse waarop die agent met die beskikbare getuienis omgaan. In die uitgediende, fondasionalistiese rasionaliteitsmodel is die rol van die agent geminimaliseer. Die rasionaliteit van 'n oortuiging is eerder gekoppel aan die manier waarop die oortuiging aan genoegsame getuienis daarvoor (veral deur logiese relasies) verbind kon word. In die alternatiewe model word die rasionele agent as vertrekpunt geneem, en die rasionaliteit van 'n oortuiging word nou bepaal deur die manier waarop die agent met getuienis omgaan (Van Huyssteen, 1995:19).

- 'n Tweede kenmerk van ' $n$ rasionele agent is die vermoé om oordele te vel in situasies waar genoegsame reëls vir besluitneming ontbreek. 'n Implikasie hiervan is dat ons vermoë om op te tree as rasionele agente beperk sal word deur die mate van kundigheid waaroor ons beskik.

- Die derde kenmerk behels die inbring van 'n sosiale element: rasionele besluitneming is ' $n$ sosiaal bemiddelde eerder as 'n reël-beheersde proses. Vir 'n oortuiging om rasioneel te wees en gebaseer te wees op 'n oordeel wat gevel is, moet dit voorgelê word aan die gemeenskap van mense wat die relevante kundigheid deel. Hiermee word rasionaliteit dan ook 'n sosiale fenomeen (Van Huyssteen, 1995:20; Brown, 1988:187).

Die gevolgtrekking ten opsigte van intelligibiliteit as epistemiese waarde by Van Huyssteen is dat die nastreef van intelligibiliteit, as die maak van die mees progressiewe teoriekeuses, vir hom saamhang met 'n breër, meer holistiese en pragmatiese opvatting van rasionaliteit. In hierdie pragmatiese opvatting van rasionaliteit word die kognitiewe, reëlgebonde dimensie van kennisvorming doclbewus onderspeel, ten einde weg te kom van 'n fondasionalistiese 
rasionaliteitskonsepsie. In die maak van die mees progressiewe teoriekeuses speel die rasionele agent, wat rasionele oordele vel, 'n besondere rol. Hierdie agent is ' $n$ méns wat strewe na intelligibiliteit. Menslike oordeel is egter altyd feilbaar en voorlopig en daarom is die beste kans om foute uit te skakel daarin gelee dat oordele en besluite aan intersubjektiewe kritiek onderwerp word (Van Huyssteen, 1995:21).

\title{
3. Werklikheidsbetrokkenheid as epistemiese waarde
}

Hoewel Van Huyssteen klem lê op 'n meer holistiese benadering tot rasionaliteit waarin die menslike faktor en kontrole deur die gemeenskap van kundiges 'n belangrike rol speel, blyk dit tog dat sekere postmodernistiese opvattings van rasionaliteit en wetenskap hom tot kommer stem. Dit is veral dié standpunte wat alle pogings tot kontak met die werklikheid laat vaar en wetenskap blóót op pragmatiese gronde bedryf. In sodanige opvattings word die klem geplaas op lokale kontekste van ondersoek: daar word slegs na afgegrensde probleme gekyk, sonder om te probeer vasstel hoe sulke probleme inskakel by die geheelbeeld wat aangaande die werklikheid gehuldig word. Eintlik word die vraag na die geheelbeeld as 'n non-vraag beskou. Van Huyssteen se weerstand teell so 'n benadering blyk uit die volgende aanhaling:

\begin{abstract}
... we cannot remain content with a pluralism of unrelated languages if they are languages about the same world. Thus, if we seek a coherent interpretation of all experience, we cannot avoid the search for a unified worldview ... A pragmatism that shuns the cognitive dimension of rationality will be an impoverished pragmatism ... Also, why should anything be conceptually powerful or pragmatically useful unless it somehow relates, through the language we use to the way things are? (Van Huyssteen, 1993c:373, 374).
\end{abstract}

Dit blyk dus dat Van Huyssteen, in sy argument teen 'n antirealistiese en bloot pragmatiese opvatting van wetenskap, klem lê op die kognitiewe aspek van rasionaliteit wat nie buite rekening gelaat mag word nie. Die kognitiewe aspek word skynbaar veral belangrik wanneer ons 'n geheelbeeld van die werklikheid (unified world view) wil kry. Uit die aanhaling word dit duidelik dat "ervaring", soos uitgedruk in "taal", vir Van Huyssteen belangrike aspekte is van 'n model van hoe daar in die wetenskap by die werklikheid uitgekom word. Die epistemiese waarde onder bespreking het dus te make met die werklikheidsbetrokkenheid van teoretiese uitsprake. Van Huyssteen verwys na die model wat hy voorstaan as 'n krities-realistiese model.

In die behandeling van Van Huyssteen se krities-realistiese rasionaliteitsmodel moet in gedagte gehou word dat die model in die eerste plek as rasionaliteitsmodel vir die teologie aangebied word. Die wetenskapsteoretiese aspekte word dus alreeds vanuit die staanspoor deur hom op teologiese teoretisering van 
toepassing gemaak. Aangesien daar in hierdie artikel spesifiek gefokus word op die wetenskapstcoretiese aspekte van Van Huyssteen se wcrk, word 'n skeiding gemaak tussen die wetenskapsteoretiese en teologiese aspekte van sy model wat soms kunsmatig kan wees, maar wat in die lig van die onderwerp onder bespreking as geregverdig beskou word.

Dit blyk dat Van Huyssteen, ten opsigte van die kwessie van werklikheidsbetrokkenheid, in sy argumentasie nou aansluiting vind by 'n rigting in die wetenskapsfilosofie genaamd wetenskaplike realisme (vgl. Van Huyssteen, 1987: $174,175)$. Die debat insake wetenskaplike realisme wentel rondom daardie teoretiese terme wat na entiteite verwys waarvan die bestaan slegs uit die teorie(ë) waarbinne hulle voorkom, afgelei kan word (dink byvoorbeeld aan die terme "kwark", "gluon" en "swart gat" in fundamentele fisika, of Freud se "id" en "superego" in die psigologie). Die vraag is of daar op enige manier 'n werklike bestaan vir dié teoretiese entiteite toegeëien kan word. Diegene wat wetenskaplike realisme voorstaan, sal sê dat daar inderdaad op een of ander manier van die teorie-onafhanklike bestaan van teoretiese entiteite gepraat kan word Een van die hoofargumente wat hiervoor aangevoer word, is die empiriese sukses van hierdie teorieẽ. Terwyl variasie en nuanse by die verskillende voorstanders ${ }^{3}$ daarvan steeds in gedagte gehou word, kan die volgende vyf sake vir die doeleindes van die bespreking geneem word as die kardinale punte waarop 'n wetenskaplik realistiese standpunt rus (vgl. Laudan, 1984:219, 220; Rescher, 1987:1, 2):

1. Die werklikheid wat deur wetenskaplike teorieë beskryf word, is grootliks onafhanklik van ons denke of teoretiese stelling-innames.

2. Benewens die observasionele terme, moet die teoretiese terme in wetenskaplike teoriee ook gesien word as werklik verwysende/refererende uitdrukkings. Rofweg kan daar in ander woorde gesê word: daar bestaan substansies in die wêreld waarmee ons beste teorieë ooreenkom.

3. Wetenskaplike teorieè, realisties geïnterpreteer, is bevestigbaar en word inderdaad dikwels bevestig as synde by benadering waar. Meer onlangse teorieë is nader an die waarheid as ouer teorieè binne dieselfde domein. Hoewel dit 'n hoogs gelade begrip is, sou gesê kon word dat realiste tipies 'n korrespondensieteorie van waarheid aanvaar.

4. Die historiese vooruitgang van die volwasse wetenskappe is grootliks 'n saak van opeenvolgende akkurater benaderings van die waarheid aangaande

3 Hier kan gedink word aan dic werk van oa. Eman McMullin, Richard Boyd, Hilary Putnam cn Jarrett Leplin (vgl Leplin, 1984) 
waarneembare en nie-waarneembare fenomene. Die implikasie hiervan is dat latere teorieé voortbou op hulle voorgangers. 'n Verdere kwalifisering van hierdie punt is dat opeenvolgende teorieë van so 'n aard sal wees dat hulle die teoretiese verhoudings en die oënskynlike verwysings van vroeëre teorieë bewaar, dit wil sê vroeëre teorieë sal spesiale gevalle van die lateres wees. Aanvaarbare nuwe teorieë behoort ook te verklaar waarom hulle voorgangers suksesvol was in die mate waarin hulle wel suksesvol was, en die nuwe teorieë doen dit ook. Samevattend kan gesê word dat die realis tipies glo in die konvergensie van wetenskaplike kennis.

5. Stellings 1 tot 4 vorm saam die verduideliking vir die sukses van die wetenskap. Omgekeerd is die empiriese sukses van die wetenskap die beste bevestiging van realisme.

Die mees basiese tese van wetenskaplike realisme word in soveel woorde deur Van Huyssteen van toepassing gemaak op dit wat hy sy krities realistiese model noem: "In a qualified or weak form of critical realism in theology, the focus is only on the very limited epistemological conviction that what we are provisionally conceptualizing somehow really exists" (Van Huyssteen, 1993b:255). Die vraag wat nou ontstaan is of Van Huyssteen se kritiese realisme op alle punte ooreenstem met wetenskaplike realisme en of daar dalk sekere punte is waar hy 'n ander opinie huldig as die standaard realistiese opvatting.

Kritiese realisme begin by ervaring. Volgens Van Huyssteen (1994:303) sal rasionele ondersoek en die strewe na intelligibiliteit altyd 'n antwoord inhou op dit wat ons ervaar. Daar kan dus nie metafisiese aansprake aangaande die wêreld gemaak word buite ons ervaring om nie. Aan die ander kant is 'n naïef-realistiese standpunt wat sê dat kennis aangaande die werklikheid direk en onbemiddeld uit ervaring verkry kan word ook vir hom onaanvaarbaar. Volgens hom is ons kennis aangaande die werklikheid altyd bemiddel deur taal. Kennis begin by ervaring, maar die ervaring is dadelik geinterpreteerde ervaring sodra ons in taal daaraan uitdrukking gee. Taal, as geïnterpreteerde ervaring is, so gesien, ons enigste epistemiese toegang tot die werklikheid. Maar as dit die geval is, hoe kan daar dan van enige vorm van realisme sprake wees? Is antirealisme nie tog maar die enigste uitweg nie? Volgens Van Huyssteen is daar tog 'n manier waarop ons - juis deur die bemiddeling van taal - by die werklikheid kan uitkom. Hierdie proses geskied deur daardie belangrike karaktertrek van taal, naamlik die metaforiese potensiaal daarvan. In die metaforiese aard van taal kom volgens Van Huyssteen ook die kognitiewe en verwysende dimensies daarvan na vore 157) en ook Delaney (1985). 
dimensies wat aan ons 'n toegangspoort tot die werklikheid bied (Van Huyssteen, 1993b:256).

Van Huyssteen maak dit duidelik dat die metaforiese spreekwyse vandag wetenskapsfilosofies en literêr weer in die sentrum van aandag te staan gekom het. Dit het duidelik geword dat metafore 'n sleutelrol speel in die wyse waarop daar tot kennis van die wêreld gekom word. 'n Metafoor is 'n vorm van beeldspraak waarin iets (die onbekende of minder bekende) vanuit die gesigspunt van iets anders gesien word (Van Huyssteen, 1987:161). Dit is nie 'n geval dat die een pool van die vergelyking deur die ander pool vervang kan word nie, juis in die gebruik van 'n woord of begrip in 'n vreemde konteks kom 'n nuwe en unieke betekenis tot stand - ' $n$ betekenis wat nie goedsmoeds uit enige een van die twee pole van die vergelyking afgelei kan word nie. "'n Metafoor is inderdaad ' $n$ wyse van taalgebruik waarin die taal self op 'n manier gerek word om nuwe insig te bring, iets te verstaan wat vroeër nie verstaan kon word nie" (Van Huyssteen, 1987:161). Die belangrike epistemiese implikasie van so 'n siening van metafore is, volgens Van Huyssteen, dat insig in aspekte van ons werklikheid wat nie in letterlike taalgebruik formuleerbaar is nie, deur metafoorgebruik bemiddel of ontsluit word. Waarop hier aanspraak gemaak word, is niks minder nie as dat metaforiese taal in 'n voorlopige en gekwalifiseerde sin werklik verwys. Van Huyssteen (1993b:260) stel dit soos volg:

The epistemic purpose of metaphorical language is not to transcend the world of human experience but to set limits, rather, to the range of our language. Such limits establish a domain for human knowledge, and our subjective encounter of the world is therefore of the same order as our recreation of the world in language. 5

Dit is aan die ander kant ook belangrik om te onthou dat Van Huyssteen se realisme ' $n$ kritiese realisme is. Volgens hom is ons kennis van die werklikheid altyd bemiddelde kennis: omdat ervaring uitgedruk word in taal, speel die kenner 'n konstitutiewe rol in die totstandkoming van kennis; daarom is teorieè altyd voorlopig en oop, en is teoretisering 'n voortgaande en kritiese proses (Van Huyssteen, 1993b:256). Nietemin is dit duidelik dat Van Huyssteen, via sy siening van die metaforiese aard van taal, tog aanspraak sal maak daarop dat die sentrale terme van wetenskaplike teoriee op een of ander manier verwys ${ }^{6}$.

5 Dit is natuurlik 'n ope vraag of so 'n uitspraak sonder meer aanvaar kan word. Strauss (1990:15-17) vocr aan dat daar by Van Huyssteen 'n onaanvaarbare kritieklose vereenselwiging van taal cn begripsvorming aanwesig is.

6 Vir 'n posisic soortgelyk aan dic van Van Huysstcen, en vir 'n uitecnsetting van die verhouding tussen metafoor, verwysing en werklikheid, kyk Soskice (1987) 
Die waarheidsvraag is tradisioneel nou verbonde aan die vraagstuk van menslike denke en die werklikheidsbetrokkenheid daarvan. Volgens Van Huyssteen (1995:24) het die epistemiese mislukking van fondasionalisme ons met geen sterk waarheidsaansprake gelaat nie. Die opvatting dat 'n uitspraak waar is wanneer dit ooreenstem met die werklikheid (die korrespondensieteorie van waarheid) word eenvoudig vandag wetenskapsfilosofies as naïef en uitgedien beskou. Dit wil voorkom of Van Huyssteen voel dat dit nie nodig is om ten opsigte van die waarheidskwessie 'n keuse te maak tussen of objektivisme óf subjektivisme nie (vgl. Van Huyssteen \& Du Toit, 1989:10-12). Vir hom moet waarheid nie so eng aan realisme verbind word nie, maar moet dit gesien word binne die konteks van 'n meer holistiese rasionaliteitsopvatting. Hoewel Van Huyssteen dit nie self doen nie, sou miskien gesê kon word dat hy sy opvatting van waarheid, naas die kognitiewe, ook wil verbind aan die ander twee bronne van rasionaliteit wat hy onderskei, naamlik die evaluatiewe en die pragmatiese.

Ten opsigte van die evaluatiewe aspek van rasionaliteit sou gesê kon word dat Van Huyssteen, in sy waarheidsbegrip, nou aansluiting vind by die opvatting van 'n rasionele agent - dit kom tot uiting in die relasionele waarheidsbegrip waartoe hy simpatiek gesind is. Dat waarheid relasioneel is, beteken volgens Van Huyssteen dat dit nie objektivisties heeltemal los van die mens vir die mens kan bestaan nie. Ook kan die waarheid nie subjektivisties deur die mens geskep word nie, maar kan dit eerder binne 'n relasie, binne die betrokkenheid van die mens op iets anders onthul word. "Waarheid" is dus nie iets totaal buite die mens nie. Immers, soos wat die mens taal en begrippe aanleer, so word hy ook deur die denkklimaat van sy tyd beinvloed ten opsigte van wat "waar" of "geloofwaardig" is (Van Huyssteen \& Du Toit, 1989:10-12).

Die ander aspek van rasionaliteit wat volgens hierdie interpretasie van Van Huyssteen se waarheidsbegrip daarop inspeel, is die pragmatiese. Hiervolgens bestaan die band tussen rasionaliteit en waarheid daarin dat ons rasioneel te werk gaan in ons pogings om die waarheid te "ontdek", en dat ons daardie gevolgtrekkings van ons wat rasioneel aanvaarbaar is, neem as die beste skattings van die waarheid waaroor ons beskik (Van Huyssteen, 1995:24). Hierdie siening is ingebed in 'n feilbare (fallibilist) epistemologie wat impliseer dat die waarheid nooit - in hierdie bedeling - volkome bereik kan word nie (vgl. Van Huyssteen, 1995:28). Wetenskaplike realisme aanvaar ook dat 'n mens nooit finaal op empiriese gronde sal kan sê dat 'n teorie waar is nie, maar hou tog vol dat opeenvolgende teorieë nader aan die waarheid is. Daar word gepraat van waarheidsbenadering en die bewys wat hiervoor gegee word, is die sukses van die wetenskap. Op hierdie punt stem Van Huyssteen egter nie saam nie. Volgens hom wys die geskiedenis van die wetenskap duidelik dat vooruitgang gepaard gegaan het met revolusies en radikale skuiwe. Konvergensie van waarheid is dus onaanvaarbaar. In wetenskaplike navorsing word daar, volgens Van Huyssteen, 
eerder tot ' $n$ skatting van die waarheid gekom. Hierdie skatting van die waarheid impliseer die volgende benaderingswyse: vel, so goed as moontlik, 'n beredeneerde oordeel van waar die waarheid van 'n saak geleê is. Die enigste manier waarop ons kan sê dat die huidige status van wetenskaplike teoretisering ' $n$ verbetering is op die verlede, is daarin gelee dat die huidige beeld wat ons van die werklikheid het, ' $n$ beter (nie noodwendig nader) skatting is, in die sin dat dit 'n groter hoeveelheid data akkommodeer

Word Van Huyssteen se opvatting van waarheid nou in oënskou geneem (veral die onmoontlikheid van waarheidsbenadering), dan blyk dit dat hy ten opsigte daarvan ' $n$ meer genuanseerde standpunt huldig as die algemene wetenskaplikrealistiese standpunt soos wat dit hierbo beskryf is. Moontlik sal gesê kan word dat hy, wat sy siening van die waarheid betref, 'n middelposisie tussen realisme en antirealisme inneem. In dié verband sluit hy aan by die werk van Nicholas Rescher (vgl. byvoorbeeld Rescher, 1987:41-44).

\section{Die saambindende faktor: vooruitgang in die wetenskap}

Dit word in hierdie artikel geargumenteer dat die saambindende faktor binne Van Huyssteen se denke oor die epistemiese waardes van intelligibiliteit en realisme die gedagte van vooruitgang in die wetenskap is. Van Huyssteen se siening van progressie in die wetenskap word gegee binne sy uiteensetting van 'n geldige teologiese rasionaliteitsmodel. Nogtans kan dit, met die nodige veranderinge, ook meer algemeen wetenskapsfilosofies gestel word. Volgens hom kan die oplos van hetsy empiriese of konseptuele probleme gesien word as die kern van 'n vooruitgangsmodel vir die wetenskap. Vooruitgang in die wetenskap vind dan plaas wanneer daar gekies word vir ' $n$ bepaalde teorie wat ' $n$ beter oplossing vir 'n probleem bied as 'n ander een. Van Huyssteen (1988:85) stel dit soos volg. "Explanatory progress in theology thus shows itself to be a form of inference to the best explanation ..." 'n Beter oplossing vir 'n empiriese of konseptuele probleem hou tegelyk 'n verhoging in intelligibiliteit in. Die vraag ontstaan nou: in terme waarvan kan gesê word dat een teorie 'n beter verklaring bied as 'n ander? Die hele kwessie van realisme en werklikheidsbetrokkenheid kom hier weer aan die orde. Sou 'n mens kon sê dat een teorie beter as 'n ander is omdat dit nader aan die waarheid is? Soos reeds geblyk het, is so 'n standpunt nie meer vir Van Huyssteen aanvaarbaar nie (in sommige van die vroeëre geskrifte, bv. 1987 en 1988, het hy wel nog van 'n gekwalifiseerde vorm van waarheidsbenadering gepraat, maar in die lateres glad nie). Om enigsins deurslaggewende getuienis vir die keuse tussen kompeterende teorieè by die "werklikheid" te kry, is volgens hom nie moontlik nie. Die enigste doel wat ' $n$ idee van 'n denkeonafhanklike realiteit nog kan hê, is dat dit as 'n soort onbereikbare ideaal kan dien vir die wetenskap om na te streef. Van Huyssteen (1995:34) stel dit soos volg: ".. realism is a position to which we are constrained not by the push of 
evidence, but by the pull of purpose". Deur die opvatting van vooruitgang in die wetenskap word die nastreef van intelligibiliteit dus verbind aan 'n pragmatiese of funksionele vorm van realisme.

\section{5. 'n Postfondasionalistiese rasionaliteitsmodel?}

Van Huyssteen se siening van die wyse waarop die mees progressiewe teoriekeuses gemaak word, kan op 'n manier gesien word as tiperend van sy hele opvatting van rasionaliteit. Net soos daar vir of teen 'n teorie gekies word deurdat die kensubjek, met al die subjektiwiteit van sy eie konteks, in ' $n$ relasie te staan kom tot die kenobjek wat in sy ervaring na hom toe kom, so bestaan die meer holistiese rasionaliteitsmodel wat Van Huyssteen voorstaan uit 'n realistiese (kognitiewe) komponent, maar ook uit 'n evaluatiewe en 'n pragmatiese komponent. Op dié manier hoop hy om die dooiepunt wat deur 'n keuse tussen of ' $n$ fondasionalistiese of ' $n$ antifondasionalistiese standpunt geskep word te deurbreek. Die vraag bly egter staan of so 'n relasionele benadering werklik daarin slaag om 'n nuwe antwoord te gee op die vraagstuk hoe die epistemologiese gaping tussen denksubjek en kenobjek oorbrug kan word. Die standpunt word hier gehuldig dat daar in die komplekse en genuanseerde uiteensetting van Van Huyssteen 'n eklektiese benadering aanwesig is - 'n benadering waarin sekere komponente meer neig na die fondasionalistiese kant en sekere komponente weer meer na die antifondasionalistiese kant. Hierdie divergerende komponente word dan saamgebind deur die gedagte van vooruitgang in die wetenskap. Die gevolg is dat dit uit die geheelbeeld lyk of 'n derde alternatief gegee word. Die volgende vraag moet egter indringend gevra word: kan Van Huyssteen in werklikheid aanspraak maak op 'n integrale derde wyse van teoretisering wat nie fondasionalisties of antifondasionalisties is nie, maar post-fondasionalisties? Uit die voorafgaande bespreking van die kern epistemiese waardes in hierdie rasionalisteitsmodel, is dit te betwyfel of dit die geval kan wees.

Van Huyssteen verbind die epistemiese waarde van intelligibiliteit eng aan die pragmatiese idee van die aanvaarding van dié teoriee wat probleme die beste oplos. Só 'n benadering neig na 'n antifondasionalisme wat nie erns maak met die werklikheidsbetrokkenheid van teorieë nie, en waarvan Van Huyssteen juis wil wegstuur. Aan die ander kant is daar die waarde van kritiese realisme. Hierdie waarde staan volledig binne die spanning tussen fondasionalisme en antifondasionalisme. In sy meer realistiese uitlopers neig dit na die fondasionalistiese kant toe met 'n aanspraak op werklikheidsbetrokkenheid, waarop ontwyfelbare kennis dan verder gebou kan word. Sy meer antirealistiese uitlopers staan weer nader aan ' $n$ antifondasionalistiese standpunt wat nie in kontak met die werklikheid belangstel nie, en wat wetenskap bloot op pragmatiese gronde wil bedryf. Om die gedagtes van werklikheidsbetrokkenheid 
en waarheid van mekaar los te maak, sal ook nie help nie, want of 'n mens nou ten opsigte van werklikheidsbetrokkenheid nader aan 'n realistiese standpunt staan en ten opsigte van waarheid nader aan 'n antirealistiese standpunt, dit bring jou nog nie buite die realisme-antirealismedebat asook die korrelaat daarvan, die fondasionalisme-antifondasionalismedebat nie.

Terwyl dit toegegee word dat intelligibiliteit en realisme belangrike epistemiese waardes in 'n rasionaliteitsmodel is, moet daarby gevra word of die idee van vooruitgang in die wetenskap die mees bevredigende manier sou wees om die verband tussen dié twee waardes te lê. Deur vooruitgang en sukses die sluitstuk van die model te maak, verkry die hele model immers 'n pragmatistiese kleur. Die standpunt word hier gehuldig dat daar ook ander moontlike maniere bestaan om dié twee waardes aan mekaar te koppel - maniere waardeur die innerlike kontak wat daar tussen hierdie waardes bestaan duideliker na vore gebring kan word, terwyl die integriteit van die gesprek met die huidige wetenskapsfilosofiese probleembewussyn steeds behou word.

Een so 'n manier word indirek deur Michael Polanyi gehanteer as hy die opkoms van die meganistiese wêreldbeeld beskryf (Polanyi, 1958:6). Die opkoms van die meganistiese wêreldbeeld hang saam met wat beskryf kan word as die skeiding tussen die epistemiese waardes van intelligibiliteit en realisme. Voor die opkoms van die meganistiese wêreldbeeld was daar 'n tradisie van kennisvorming waarin die kennende mens luister na die inherente intelligibiliteit in die natur. Hierdie tradisie het al by die Pythagoreërs bestaan, wat die heelal uitsluitlik in terme van getalle wou verklaar. In 'n sekere sin het hulle op 'n mistieke wyse "geluister" na die eenvoudige geometriese harmonie van die heelal. Hierdie tradisie is, volgens Polanyi $(1958: 6,7)$, voortgesit deur Copernicus en Kepler. Die bewondering vir die harmonieuse beweging van die hemelligame en die eenvoud van die formules waarmee dit beskryf kon word, was tot 'n groot mate verantwoordelik vir die opgang van die heliosentriese wêreldbeeld. Natuurlik was hierdie sentimente grootliks ingebed binne 'n neo-Platonistiese wêreldbeeld. Die punt is egter dat daar ' $n$ besef was van die inherente rasionaliteit in die natuur waarmee kontak gemaak is deur die rasionaliteit van die teorieê wat gebruik is om die ervaring van die natuur te verklaar.

Met die oorgang vanaf Kepler na Galilei figureer getalle vir die eerste keer as afgemete hoeveelhede binne wiskundige formules. Algaande het 'n materialistiese benadering tot die objekte van kennis die oorhand begin kry. Volgens hierdie denkwyse is slegs die meganiese eienskappe (afmetings) van dinge primêr - die ander eienskappe soos byvoorbeeld kleur en smaak is sekondêr en berus op konvensie. Met die opkoms van die meganistiese wêreldbeeld het ' $n$ belangrike verandering plaasgevind in die opvatting van teoretiese kennis. Getalle en geometriese vorme is nie langer gesien as inherent in die natuur nie. Teorieẽ het 
nie langer iets raakgevat van die innerlike rasionaliteit aan die natuur nie; dit het nie langer die harmonie in die Skepping as objek gehad nie (Polanyi, 1958:8). Die verdere ontwikkeling van hierdie tendens het tot 'n skeiding tussen rede en ervaring gelei; wiskunde is geïdentifiseer met rasionele denke en noodwendige waarheid, terwyl alle ervaring van die werklikheid as kontingent gesien is. Die opkoms van die positivisme teen die einde van die vorige eeu is in 'n sekere opsig die kulminasie van hierdie ontwikkeling, met wetenskaplike teoriee wat enige aanspraak op inherente rasionaliteit ontneem is. Deur hierdie ontwikkeling is intelligibiliteit in die sin van rasionaliteit algaande verwyder uit die kenbare. Die denksubjek is geneem as op homself aangewese om intelligibiliteit aan die kenobjek te verleen. Die gevolg was 'n debat of daar ooit deur wetenskaplike teoriee by die werklikheid uitgekom kan word.

Die benadering tot kennisvorming wat gevolg is deur die Nederlandse filosoof, Herman Dooyeweerd, stem in dié opsig ooreen met die benadering van Polanyi in die sin dat dit ook die radikale splitsing tussen die subjek en die objek wat in die moderne tyd plaasgevind het, bevraagteken. Dooyeweerd wil nie 'n radikale skeiding maak tussen denke en werklikheid nie, maar plaas denke eerder binne die kosmos en maak dit ondergeskik aan die ordening van die totale kosmos. Die logiese aspek van die geskape werklikheid vorm dus 'n faset van 'n ordening van die werklikheid wat veel wyer strek as slegs die logiese. Die implikasie hiervan is dat denke nie die werklikheid skep nie (idealisme), maar ook dat daar nie 'n radikale breuk tussen denke en nie-denke bestaan nie. Juis die feit dat denke deel is van die kosmologies-geordende skepping maak kennis moontlik, want daar bestaan ' $n$ band tussen menslike denke en die werklikheid buite die menslike denke. Hierdie ordening van die werklikheid het Dooyeweerd, vanuit sy Christelike perspektief, aan die wet van God toegeskryf (vgl. Henderson, 1994:96,103).

In die tradisie wat in die lyn van Dooyeweerd voortwerk, word die mening soms gehuldig dat die probleme van realisme en nominalisme, subjektivisme, relativisme en objektivisme in die wetenskap te wyte is aan die absolute skeiding wat deur die rasionalisme gemaak is tussen denksubjek en kenobjek. Eeue lank al probeer die epistemologie hierdie gaping oorbrug deur soms die rol van die denksubjek te beklemtoon (subjektivisme) en soms weer die rol van die kenobjek (objektivisme). Daar word geworstel met die vraag of die objek die wet vir die subjek is, en of die teer.oorgestelde eerder waar is. Tans word dit algemeen aanvaar dat kennis van objekte nie as bruta facta uit sintuiglike ervaring verkry kan word nie; die subjektiviteit van die waarnemer speel 'n beslissende rol. Die gevolg van hierdie insig is die vele posisies tussen realisme en antirealisme wat tans in die wetenskapsfilosofie aangetref word. Die argument loop dan verder dat die radikale (ontologiese) gaping tussen subjek en objek op prinsipiêle gronde ontken moet word. In plaas daarvan om die wet of in die subjek, of in die objek 
te soek, word aangevoer dat die wet 'n heeltemal ander synde is waaraan sowel die denksubjek as die kenobjek onderworpe is. Die wet vind sy bestaan daarin dat dit vir dinge geld. Die standpunt word gehuldig dat sowel die subjek as die objek deur God onder dieselfde wetsorde gestel is, dit wil sê hulle behoort tot dicselfde ontiese (kosmiese) orde (Ouweneel, 1993:191). Daar bestaan dus in beginsel nie 'n onoorbrugbare gaping tussen die menslike rasionele subjek en ander rasionele subjekte asook die nie-menslike natuur nie, aangesien die dinge almal saamgebind word deur die feit dat dit aan die wet onderworpe is. Ouweneel (1993:193) stel dit soos volg:

Subject and object themselves are subject to the structural norms which hold for them. The two, man with his logical subject function and the thing with its logical object function, have been 'layed-out' for one another. Through this creational order, all entities ... creationally hang together.

Die feit dat daar nie 'n radikale (ontologiese) gaping tussen denksubjek en kenobjek bestaan nie, het implikasies vir die epistemiese waardes van intelligibiliteit en realisme. Hoewel een of ander vorm van realisme of kritiese realisme waarskynlik steeds gehuldig sal word (volgens Henderson, 1994:92, het Dooyeweerd soms na sy siening verwys as kritiese realisme; vgl. ook Ouweneel, 1993:186, 187), is die standpunt wat gestel moet word dat daar 'n innerlike verband bestaan tussen die waardes van intelligibiliteit en realisme. Juis omdat die objekte van kennis deel is van dieselfde geordende werklikheid is daar ' $n$ inherente intelligibiliteit in hulle. Dit hang nie van die denksubjek af om intelligibiliteit van buite af daaraan toe te ken nie.

Die gevolgtrekking waartoe aan die einde van hierdie bespreking gekom word, is dat intelligibiliteit en kritiese realisme inderdaad kérn epistemiese waardes van enige wetenskaplike rasionaliteitsmodel sal wees. Dit is egter te betwyfel of Van Huyssteen in die uiteensetting van sy rasionaliteitsmodel en deur die gebruikmaking van die waardes van intelligibiliteit en realisme daarin geslaag het om aan die fondasionalisme-antifondasionalismedebat te ontkom. Deur die idee van vooruitgang in die wetenskap die saambindende faktor van sy rasionaliteitsmodel te maak, verkry die model 'n pragmatistiese kleur wat dit in elk geval neig na die antifondasionalistiese kant toe. Daarbenewens moet die verband tussen intelligibiliteit en realisme ook op 'n dieper vlak gesoek word as op die vlak van vooruitgang.

\section{Bibliografie}

BROWN, H I. 1988. Rationality London: Routledge.

DANCY, J. 1985. Introduction to contemporary epistemology. Oxford : Blackwell.

DELANEY, C.F. 1985 Presidential address: Beyond realism and anti-realism Proceedings of the American Catholic Philosophical Association. Notre Dame 
Epistemiese waardes in die rasionaliteitsmodel van Wentzel van Huyssteen

HART, H. 1981. The impasse of rationality today. (In Blokhuis, P. et al., reds. Wetenschap, wijsheid, filosoferen. Assen : Van Gorcum. p. 174-199.)

HENDERSON, R.D. 1994. Illuminating law: The construction of Herman Dooyeweerd's philosophy. Amsterdam : Vrije Universiteit. (Ph.D.-proefskrif.)

KRUGER, J.S. 1987. Resensie in: Theologia Evangelica, 20(1):64-70.

LAUDAN, L. 1984. A confutation of convergent realism. (In Leplin, J ed Scientific realism Berkeley : University of California Press. p. 218-249.)

LEPLIN, J. 1984. Scientific realism. Berkeley : University of California Press

OUWENEEL, W.J. 1993. A critical analysis of the external and internal prolegomena of systematic theology (vol. 1). Bloemfontein : UOVS. (D.Theol. dissertation.)

POLANYI, M. 1958. Personal knowledge: Towards a post-critical philosophy. London Routledge \& Kegan Paul.

RESCHER, N. 1987. Scientific realism - A critical reappraisal. Dordrecht : Reidel.

RORTY, R. 1989. Pragmatism and philosophy. (In Baynes, K., Bohman, J., McCarthy, T After philosophy - End or transformation? Cambridge, Mass. : MIT Press. p. 26-63.)

SMIT, D.J. 1988. Theology as critical account of personal faith? (In Mouton, J, Van Aarde A.G., Vorster, W.S. eds. Paradigms and progress in theology. Pretoria : Human Sciences Research Council. p. 91-112.)

SOSKICE, J.M. 1987. Metaphor and religious language. Oxford : Clarendon Press.

STRAUSS, D.F.M. 1991. Wat is teologie? Tydskrif vir Christelike Wetenskap, 27(2):1-22.

VAN DER MERWE, N T. 1983. Rationality and Scripture: Outline of a philosophical approach (In Hart, H. et al., reds. Rationality in the Calvinian tradition. Lanham University Press of America. p. 319-359.)

VAN HUYSSTEEN, W. 1987. Teologie as kritiese geloofsverantwoording. Pretoria : Raad vir Geesteswetenskaplike Navorsing.

VAN HUYSSTEEN, W. 1988. Paradigms and progress: inference to the best explanation? (In Mouton, J., Van Aarde, A.G., Vorster, W.S eds. Paradigms and progress in theology. Pretoria Human Sciences Research Council. p. 81-90.)

VAN HUYSSTEEN, W. \& DU TOIT, B 1989. Geloof en Skrifgesag. 'n Analise van die Skrifgesagprobleem na aanleiding van die rapport 'God met ons' Pretoria : NG Kerkboekhandel.

VAN HUYSSTEEN, W. 1993a. Theology and science: The quest for a new apologetics. The Princeton Seminary Bulletin, 14(2):113-133.

VAN HUYSSTEEN, W. 1993b. Critical realism and God: can there be faith after foundationalism? (In Van Niekerk, H., Esterhuyse, W. en Hattingh, J. reds. Intellektueel in konteks - Opstelle vir Hennie Rossouw. Pretoria : Raad vir Geesteswetenskaplike Navorsing. p. 253-266.)

VAN HUYSSTEEN, W. 1993c. What epistemic values should we reclaim for religion and science? A response to J. Wesley Robbins. Zygon - Journal of Religion and Science, 28(3):371-375

VAN HUYSSTEEN, W. 1994 Is there still a realist challenge in postmodern theology? On religious experience and explanatory commitments in Jerome Stone's "A minimalist vision of transcendence". American Journal of Theology \& Philosophy, 15(3) 293-304

VAN HUYSSTEEN, J W. 1995. The shaping of rationality in science and religion. (Paper submitted for a conference on "Religion and science" (March 1995) at the Royal lnstitute of Philosophy, University of Warwick, UK.) $45 \mathrm{p}$.

VAN NIEKERK, A. 1992. Rasionaliteit en relativisme - Op soek na 'n rasionaliteitsmodel vir die menswetenskappe. Prctoria : RGN Uitgewers

WOLTERSTORFF, N. 1984. Reason within the bounds of religion Grand Rapids : Eerdmans. 